\title{
The determinants of vote intentions in Portugal*
}

\author{
FRANCISCO JOSÉ VEIGA ${ }^{1} \&$ LINDA GONÇALVES VEIGA ${ }^{2}$ \\ $1 / 2$ Núcleo de Investigação em Políticas Económicas (NIPE), Universidade do Minho, \\ P-4710-057 Braga, Portugal; E-mail: ${ }^{1}$ fjveiga@eeg.uminho.pt; ${ }^{2}$ linda@eeg.uminho.pt
}

\begin{abstract}
This paper offers new insights on the interactions between economics and politics in Portugal. We use two unexplored data sets consisting of monthly polls on vote intentions for the main political parties in Portugal and responses to a consumer survey containing a battery of questions on economic evaluations. The analysis covers the interval from 1986 to 2001. We find that: (1) right-wing governments are penalized for higher inflation while the left-wing ones are not, (2) left-wing governments are more penalized for increases in the unemployment rate; (3) voters base their evaluations of incumbents' performances on perceptions of past and current economic conditions, rather than on expected future economic outcomes.
\end{abstract}

\section{Introduction}

Following seminal papers by Mueller (1970) and Kramer (1971) for the U.S. and Goodhart and Bhansali (1970) for the U.K., the analysis of the impact of economic conditions on politicians' popularity levels and electoral results has become one of the most active research fields in public choice. Although the international literature is already quite extensive, ${ }^{1}$ there is only one published paper about the Portuguese case. ${ }^{2}$ With this research we try to fill this gap by investigating the determinants of vote intentions for the main parties in Portugal.

We start by using an unexplored data set consisting of monthly polls on vote intentions from 1986 to 2001. Our first set of estimations suggest that (1) socialist governments had less electoral support than social democratic governments; (2) recently elected governments enjoyed a honeymoon period with the electorate; (3) longer time in office decreased vote intentions favoring the governing party; (4) unfavorable economic outcomes, especially inflation and

* We acknowledge helpful comments from Henry Chappell, Martin Paldam, Torben Iversen, one anonymous referee, participants at the 2001 European Public Choice Society Meeting and at the 2002 Meeting of the Public Choice Society. We also express our gratitude for the financial support of the Portuguese Foundation for Science and Technology under research grants POCTI/99/ECO/32609 and POCTI/2001/ECO/37457 (partially funded by FEDER). Finally, this paper benefited from the efficient research assistance of Cláudia Ribeiro. 
unemployment, negatively affected vote intentions for the incumbent party, providing evidence in favor of the responsibility hypothesis.

When testing for partisan interaction effects, we find that social democratic governments were penalized for higher inflation while socialist governments were not, but the latter tended to be more penalized for increases in the unemployment rate. These results are in sharp contrast with Swank's (1993) partisan model, since he argues that the right should benefit from higher inflation and the left from higher unemployment. Thus, Portuguese voting behavior seems to comply better with the ideological responsibility hypothesis of Powell and Whitten (1993). That is, governments tend to be penalized more severely when they perform poorly with respect to the variable they considered most important.

Finally, we use data on the consumer survey implemented by the National Institute of Statistics to test whether Portuguese voters are prospective or retrospective. Results clearly show that the electorate relies on their perceptions of past and current economic perspectives when evaluating the incumbents' performance, rather than on expected future outcomes. Thus, voters are retrospective.

The paper consists of seven sections. Sections 2 and 3 provide some background on Portuguese parties and on the structure of the political system. Section 4 describes the data set. Section 5 models the determinants of vote intentions. Section 6 presents the empirical results and, finally, Section 7 reports the conclusions.

\section{Political parties in Portugal $^{3}$}

The military coup of 25 April 1974 re-established democracy in Portugal. It was followed by a two-year period of severe political instability during which the Junta of National Salvation and six provisional governments ruled the country. Following its approval, the new Constitution came into effect on 25 April 1976, and legislative elections were held on the same day. Since then, four political parties have dominated Portuguese political life. The center-left Socialist Party - Partido Socialista (PS) and the center-right, or liberal, People's Democratic Party / Social Democratic Party - Partido Popular Democrata / Partido Social Democrata (PPD/PSD) have always been the two major political parties, alternating in power since $1976 .{ }^{4}$ The left-wing Portuguese Communist Party - Partido Comunista Português (PCP) and the right-wing, or Christian Democratic, Democratic and Social Center / People's Party - Centro Democrático e Social / Partido Popular (CDS/PP) $)^{5}$ have contested the third position and, except for brief periods in which CDS/PP was part of coalition governments, they have been in the opposition. As can be 
Table 1. Legislative electoral results

\begin{tabular}{|c|c|c|c|c|c|c|}
\hline & PS & PPD/PSD & CDS/PP & $\mathrm{AD}$ & PCP & $\begin{array}{l}\text { Effective number } \\
\text { of parties }^{\mathrm{a}}\end{array}$ \\
\hline $1975^{\mathrm{b}}$ & $37.87 \%$ & $26.39 \%$ & $7.61 \%$ & & $12.46 \%$ & 4.23 \\
\hline 1976 & $34.98 \%$ & $24.03 \%$ & $15.89 \%$ & - & $14.5 \%$ & 4.40 \\
\hline 1979 & $27.43 \%$ & - & - & $42.24 \%$ & $18.96 \% \mathrm{~d}$ & 3.44 \\
\hline 1980 & $27.13 \%^{\mathrm{c}}$ & - & - & $44.4 \%$ & $16.92 \% \mathrm{~d}$ & 3.33 \\
\hline 1983 & $36.35 \%$ & $27.04 \%$ & $12.38 \%$ & - & $18.2 \% \mathrm{~d}$ & 3.94 \\
\hline 1985 & $20.82 \%$ & $29.79 \%$ & $9.74 \%$ & - & $15.55 \% \mathrm{~d}$ & 5.04 \\
\hline 1987 & $22.3 \%$ & $50.15 \%$ & $4.34 \%$ & - & $12.18 \% \mathrm{e}$ & 3.12 \\
\hline 1991 & $29.25 \%$ & $50.43 \%$ & $4.38 \%$ & - & $8.84 \%^{\mathrm{f}}$ & 2.86 \\
\hline 1995 & $43.85 \%$ & $34 \%$ & $9.09 \%$ & - & $8.61 \%^{\mathrm{f}}$ & 3.09 \\
\hline 1999 & $44 \%$ & $32.32 \%$ & $8.38 \%$ & - & $9.02 \% \mathrm{f}$ & 3.19 \\
\hline 2002 & $37.84 \%$ & $40.15 \%$ & $8.75 \%$ & & $6.97 \% \mathrm{f}$ & 3.15 \\
\hline
\end{tabular}

Source: National Elections Commission.

Notes. PS - Socialist Party; PPD/PSD - People's Democratic Party / Social Democratic Party; CDS/PP - Democratic and Social Center / People's Party; AD - Democratic Alliance (PSD + CDS + PPM - Monarchic People's Party); PCP - Portuguese Communist Party. The results for the smaller parties are not shown. There are usually about a dozen parties competing in the legislative elections.

${ }^{a}$ The Laakso and Taagepera (1979) effective number of parties is equal to $1 / \Sigma\left(\mathrm{p}_{\mathrm{i}}\right)^{2}$, where $\mathrm{p}_{\mathrm{i}}$ is the percentage of votes obtained by party $i$.

${ }^{b}$ The 1975 elections served to elect the members of the Constituent Assembly, which was assigned the draft of the new Portuguese Constitution. The country was still ruled by provisional governments and the Junta of National Salvation until April 1976.

${ }^{\mathrm{c}}$ Socialist Revolutionary Front (FRS): PS + small socialist parties.

d United People's Alliance (APU): PCP + MDP/CDE (Portuguese Democratic Movement).

e Unitary Democratic Coalition (CDU): PCP + dissidents of MDP + PEV (Green-Ecologist Party).

${ }^{\mathrm{f}} \mathrm{PCP}+\mathrm{PEV}$

seen in Table 1, these four political parties account for about $90 \%$ of the votes in every election except in 1985, when the Democratic Renewal Party (Partido Renovador Democrático - PRD) won about $18 \%$ of the votes. ${ }^{6}$

It is also worth noting that since the initial phase of Portuguese democracy, when a four-party system seemed to be established, there has been a growing concentration of votes in the two parties closer to the ideological center (PS and PSD). The combined vote share of the two main parties was $59.1 \%$ in the 1976 election but has been above $75 \%$ since 1991, and the "effective number" of parties decreased from 4.23 in 1975 to 3.15 in $2002 .^{7}$ Thus, it seems that 
CDS/PP and PCP occupied the ideological spaces attributed to them in the voters' range of preferences, while the two largest parties competed for the center ground. According to Colomer (1996: 186), in a policy space ranging from 0 (extreme left) to 10 (extreme right), the positions of these four parties in 1986 were: PCP - 1.8, PS - 4.7, PSD - 7.1, and CDS/PP - 8.5 Although the PSD seems to be farther away from the center than the PS, its unifying and centripetal strategy helped consolidate political equilibrium around the center.

Changes in the social composition of the political parties also contributed to the transition to a bipartisan system (Magone, 1997). In the early years of democracy the PS was mainly supported by the new, urban middle classes and industrial workers. In the following years it expanded its electoral base to farmers and other social groups, becoming a 'catch-all' party. The PSD finds support in almost the same groups of population. Starting with the farmers in the northern Portugal and the rural and urban "petty bourgeoisie" in villages and small towns, it also developed into a 'catch-all' party, although with a more technocratic, center-right image. The Communist Party is essentially a working-class party, mainly supported by farm and industrial workers from southern Portugal and the suburbs of Lisbon and Setúbal. The Communists experienced a gradual decline in their traditional support due to modernization and depopulation of the Alentejo region. In the last two elections there was also some transfer of votes from PCP to the Left Bloc (Bloco de Esquerda), a new, more modern, and intellectual leftist party. ${ }^{8}$ Finally, the CDS/PP finds support in the higher echelons of the northern farming community and among entrepreneurs and managers. On the most disputed elections, the CDS/PP suffered from vote transfers of its usual supporters to the PSD, following the logic of useful vote.

The instability that characterized the Portuguese democracy until 1987 may have served as a learning experience for voters (Colomer, 1996). They came to prefer stable governments that have enough parliamentary support to carry their terms until the end. Thus, they prefer to vote for the major party (PS or PSD) that is closest to their ideological preferences so that it has a chance to obtain an overall majority and form a one-party government. This preference towards more stable governments also contributed to the concentration of votes in the two major parties.

\subsection{Legislative elections and governments}

In the first legislative elections for the Assembly of the Republic held in April 1976, the Socialist Party secured a plurality, with $34.98 \%$ of the votes. Mário Soares led the first Constitutional Government and the following two, all of which fell short of completing their terms. In 1979 the PSD formed the Demo- 
cratic Alliance (AD) with the CDS and the Monarchic People's Party (PPM). The AD won $42.24 \%$ of the votes in that year, getting an overall majority in Parliament. Sá Carneiro, leader and founder of PSD, became the prime minister in January 1980. In the October 1980 elections the AD renewed its overall majority of deputies but, two months later, Sá Carneiro died in an airplane accident and Pinto Balsemão was elected head of PSD and became Prime Minister. Divisions among coalition members caused the resignation of Pinto Balsemão in December 1982, and new elections were scheduled for April 1983.

In the 1983 balloting, PSD ran alone and gained the second-largest vote total. It then joined PS in a coalition government that became known as the "central bloc." In May 1985, Cavaco Silva was elected head of the Party and in June the PSD broke the coalition with PS and called for earlier elections. In July 1985, Mário Soares decided to run for the Presidency. ${ }^{9}$ Following the fall of the coalition government, the President dissolved the Assembly and called for elections in October, in which PSD gained the largest share, with 29.79\% of the votes. Cavaco Silva formed a minority government, which ended in April 1987 following a no confidence vote.

From 1985 to 1987 Portugal's economic situation improved considerably. During the 1987 election campaign Cavaco Silva emphasized the need for economic and political stability for Portugal's successful integration into the European Community. ${ }^{10}$ The electorate responded favorably to his appeal and gave PSD $50.15 \%$ of the votes in the legislative balloting of July 1987. The PSD won the first one-party overall majority since the end of the dictatorship. That majority was renewed in the legislative elections of October 1991. During the last mandate, the deterioration of Portugal's economic situation and several allegations of government members' corruption contributed to the deterioration of the government's popularity. In February 1995, Cavaco Silva abandoned the PSD leadership.

In the 1995 legislative elections the Socialist Party got $43.85 \%$ of the votes. António Guterres, the party leader since 1992, became prime minister of a PS minority government. ${ }^{11}$ After completing its term, ${ }^{12}$ the PS had its best result ever in the 1999 balloting, with $44 \%$ of the vote, which gave the party exactly $50 \%$ of the deputies in Parliament. However, the disastrous results obtained in the municipal elections of December 2001 lead to the resignation of António Guterres and his government, prompting the President to dissolve the Parliament and call for legislative elections to be held in 17 March 2002. The PS, under the leadership of Ferro Rodrigues (a minister of the previous government), finished second in these elections, obtaining $37.84 \%$ of the votes, and is now in the opposition. The PSD, under the leadership of Durão Barroso, gained a plurality with a share of $40.15 \%$. It formed 
a coalition government with the third party, CDS/PP, which received $8.75 \%$ of the votes.

\section{Brief description of the structure of the Portuguese political system}

The major governmental entities in Portugal are the President of the Republic, the Government, the Assembly of the Republic, and the Courts. The President of the Republic is elected every five years by absolute majority in two rounds. The candidates can either run as independents, or be appointed by political parties. No President can serve for more than two consecutive terms. The main duties of the President are: to serve as the head of State and the Commander-in-Chief of the armed forces; to set the dates of legislative elections after consulting the parties; to appoint the Prime Minister and the members of the Government suggested by the latter; to dissolve the Parliament and call for elections; and, to promulgate and have published laws, decree-laws and regulations. The President also has the power to veto laws and decrees, or to send them for consideration by the Constitutional Tribunal.

The Government consists of the Prime Minister, the Ministers, the Secretaries of State, and the Under-Secretaries of State. The President usually consults the political parties and takes into account recent election results when appointing or dismissing a Prime Minister, who is generally the leader of the party that received the most votes in the last election. The other members of the Government are appointed by the President after being proposed by the Prime Minister. The Government formulates the general policy of the country and is the highest organ of public administration. It has political, legislative, and executive powers. Its legislative power consists of proposing laws to the Assembly and issuing decrees. Its executive power extends to the execution of the general plans of activities and budgets of the State. The Government is responsible to both the President, who can dismiss it, and to the Assembly of the Republic, which must approve its plans and budgets and may dismiss it by passing a censure motion.

The Assembly of the Republic is the Portuguese unicameral Parliament, currently composed of 230 deputies elected for a period of four years by direct and secret universal adult suffrage. Parties present closed and blocked lists of candidates in each district and there is a proportional transformation of votes into seats, using the Hondt method. ${ }^{13}$ Since the deputies are subject to strong party discipline, act only through their groups, and may not change group, parliamentary life is dominated by the party leaderships (Colomer, 1996). The duties of the Assembly include (among others): enacting legislation in all areas except those reserved to the Government; approving amendments to the Constitution; approving the Government's general budget and plan of 
Table 2. Legislative elections and parties in government since 1985

\begin{tabular}{|c|c|c|c|c|}
\hline $\begin{array}{l}\text { Dates of } \\
\text { elections }\end{array}$ & $\begin{array}{l}\text { Winning } \\
\text { party }\end{array}$ & $\begin{array}{l}\text { Share in } \\
\text { Parliament }\end{array}$ & $\begin{array}{l}\text { Prime } \\
\text { Minister }\end{array}$ & $\begin{array}{l}\text { Form of } \\
\text { government }\end{array}$ \\
\hline 5 October 1985 & PSD & $34 \%$ & Cavaco Silva & One party, minority \\
\hline 19 July 1987 & PSD & $59 \%$ & Cavaco Silva & One party \\
\hline 6 October 1991 & PSD & $58 \%$ & Cavaco Silva & One party \\
\hline 1 October 1995 & PS & $48 \%$ & António Guterres & One party, minority \\
\hline 10 October 1999 & PS & $50 \%$ & António Guterres & One party, "minority" \\
\hline 17 March 2002 & PSD & $46 \%$ & Durão Barroso & Coalition (PSD+CDS/PP \\
\hline
\end{tabular}

Source: National Elections Commission.

Note. PSD - Social Democratic Party; PS - Socialist Party; CDS/PP - Democratic and Social Center / People's Party.

activities; passing motions of confidence in or censure of the Government; and appointing ten of the thirteen members of the Constitutional Tribunal.

\section{The data}

The period analyzed in this paper begins in June 1986 and ends in June 2001. It includes three terms of social democratic governments and two terms of Socialist governments. Table 2 describes the winning parties of legislative elections since the balloting of October 1985.

Vote intention data was obtained from a weekly national newspaper called Expresso. The source data are from polls conducted on a monthly basis by Euroexpansão employing a representative sample of about 600 Portuguese adults and conducted by telephone interviews. Economic data consists of monthly unemployment rates, seasonally adjusted and standardized; consumer price indices; industrial production indices; real exchange rates; and a confidence indicator. Most were collected from OECD - Main Economic Indicators. Exchange rates were obtained from IMF - International Financial Statistics and data on the Portuguese Consumers Survey was collected from the National Institute of Statistics (INE).

\section{Explaining vote intentions}

The model we propose to explain vote intentions includes the following elements: measures of economic conditions, leader characteristics, effects of time in office, and partisan considerations. 


\subsection{Economic performance}

According to the pioneering work of Downs (1957), voters chose rationally between alternative candidates or parties. They analyze past and announced policies of each candidate in order to make inferences about future decisions. Then, each voter casts his/her vote for the candidate that is associated with the highest expected utility. Because even a rational voter may not find it practical to collect all the information on past and announced policies and their possible consequences, Kramer (1971) and Frey and Schneider (1978) assumed that voters' decision rules are based on more readily available information. That is, they vote for the incumbent if they are satisfied with his/her economic performance, and vote against if otherwise. If we assume that past and current economic performances are good predictors of future outcomes, this behavior is consistent with expected utility maximization. ${ }^{14}$

Although the hypothesis that voters hold incumbents responsible for economic outcomes is well established in the literature and has been tested in a variety of contexts and formulations over the past thirty years, the development of its theoretical foundations in models with rational expectations has been more recent. Rogoff and Sibert (1988) developed a competency model in which the ability of parties to generate favorable economic outcomes differs. Since knowledge of ability is private information, competency cannot be observed directly by the electorate. Thus, voters base their evaluations and vote decisions on the incumbent's past policies. Similarly, in Alesina and Cukierman (1990), voters are not fully informed about the incumbent's preferences and do not observe his/her policy actions directly. However, since policy outcomes are positively correlated with policy actions, they convey information about the incumbent's preferences. Therefore, the assumption of persistence of preferences implies that voters can draw inferences about future policies and outcomes by looking at current economic conditions.

Harrington (1993) combines the two above-mentioned models by assuming that voters are uncertain about the effectiveness of policy actions, about the incumbent's future policy intentions, and about which policy the incumbent believes its best. Voters' preferences are endogenous and may change as new information is released. In such a setting, the electorate will be more sensitive to policy actions (as in Rogoff and Sibert, 1988) when it feels more confident about which policy is best, or more able to identify the consequences of policy actions. Voting behavior will be more performance-based (as in Alesina and Cukierman, 1990) when voters are more uncertain about the effectiveness of the policies chosen.

The latter case, in which voters are more uncertain of the effectiveness of policies, seems to be the most appropriate assumption for the Portuguese case. There are several reasons why this is so. First, the economic programs 
of the two biggest parties (PS and PSD) are somewhat similar and the main policy actions proposed by them are seldom clearly explained. Second, it is not unusual for Portuguese politicians to make promises during campaigns that are not fulfilled after the elections. Finally, Portugal's literacy ratio is the lowest of the European Union and is among the lowest of the OECD. This may imply that the degree of uncertainty about the effects of economic policies is greater in Portugal than in most of the other industrialized countries.

As a consequence, we expect to observe performance-based voting behavior. Since our dataset consists of polls results that, according to Nannestad and Paldam (1994: 229) tend to reflect a greater degree of voter myopia than election results, we hypothesize that voters' evaluations of the incumbents' performances are based on current economic conditions. The vector of variables we use to measure current economic conditions includes, among others, the unemployment rate, the inflation rate, and the confidence indicator. ${ }^{15}$ All variables are lagged one month because it takes time for economic data to be released and for individuals to recognize changes in economic conditions.

\subsection{Leader characteristics}

These are taken into account by including a dummy variable for each government leader. In this way, we control for leaders' personalities, charisma, or other characteristics that may influence vote intentions for his/her party. In fact, electoral scholars commonly accept the proposition that more popular leaders increase party vote intentions. ${ }^{16}$

\subsection{Time in office}

Time in office can influence vote intentions in several ways. First, recently elected parties may benefit from a honeymoon period with the electorate. This may result from the fact that the public recognizes that the incumbent is not responsible for the economic conditions that prevail during the first few months of his/her administration (see Smyth, Washburn, and Dua, 1989: 338). We control for honeymoon effects by including a variable that takes the value of six in the first month of each term, declines to one by the sixth month and takes the value of zero thereafter. Second, ruling is costly in terms of popularity and, therefore, we expect vote intentions to decline with time in office. That happens because the incumbent's policy actions, even if always supported by a majority of the electorate, will tend to alienate some voters (Mueller, 1970; and Frey and Schneider, 1978). As more and more minorities are alienated, it becomes possible for a clever opposition to forge a coalition able to overthrow the incumbent. Thus, the government's popularity will tend 
to decrease with time, as some of its former supporters get hurt by its policies and turn to the opposition. Since it is impossible to please everybody at the same time regardless of what the incumbent does, some people will not approve his/her actions. Another cause for gradual popularity decay pointed by Mueller (1970) is that much more is promised during campaigns than what can be achieved. Then, some time after an election, people become disappointed as the incumbent fails to deliver all that he/she promised. Cost of ruling effects are controlled for by including a variable measuring the number of months in office or dummy variables for each term in office.

In sum, our baseline empirical model can be described by equation (1), where $\mathrm{VI}_{t}$, the dependent variable, is the percentage of vote intentions for the incumbent party at time $\mathrm{t},(\mathrm{L}) \mathrm{VI}_{\mathrm{t}-1}$ are lags of the dependent variable, LEADER is a vector of dummy variables for party leaders, TIME is a vector of variables that capture honeymoon and cost of ruling effects, and ECO is a vector of economic variables that represent current economic conditions.

$$
\mathrm{VI}_{\mathrm{t}}=\alpha+\beta(\mathrm{L}) \mathrm{VI}_{\mathrm{t}-1}+\phi \mathrm{LEADER}_{\mathrm{t}}+\eta \mathrm{TIME}_{\mathrm{t}}+\gamma \mathrm{ECO}_{\mathrm{t}-1}+\mathrm{u}_{\mathrm{t}}
$$

\subsection{Partisan effects}

Because individuals' vote intentions may depend upon the ideology of the incumbent (Powell and Whitten, 1993; and Swank, 1993), the economic variables are interacted with dummy variables indicating which party was in office (PARTY $\left.{ }_{i}^{*} \mathrm{ECO}\right)$. The following equation is estimated in our tests for partisan effects:

$$
\mathrm{VI}_{\mathrm{t}}=\alpha+\beta(\mathrm{L}) \mathrm{VI}_{\mathrm{t}-1}+\phi \mathrm{LEADER}_{\mathrm{t}}+\eta \mathrm{TIME}_{\mathrm{t}}+\delta_{\mathrm{i}}\left(\mathrm{PARTY}_{\mathrm{i}} * \mathrm{ECO}\right)_{\mathrm{t}-1}+\mathrm{u}_{\mathrm{t}}
$$

The underlying idea goes back to Hibbs' (1977) partisan theory, according to which politics is about the distribution of income and, when in office, parties adopt policies that favor their constituencies. Hibbs admits that leftwing parties are mainly supported by the lower classes of the population that suffer the most with unemployment, while conservatives tend to find support in the upper classes that mainly dislike inflation. Therefore, the left concentrates on improving real economic conditions, while conservatives are more concerned with price stabilization.

Powell and Whitten (1993) and Swank (1993) use different approaches to introduce partisan considerations into the vote functions literature. The former authors argue that a government should be held more responsible for the variables that it, or its constituency, care about the most. Since rightwing governments are relatively more worried with the evolution of inflation 
than with that of unemployment, they will be more penalized when inflation rises. Likewise, left-wing governments are more penalized for increases in the unemployment rate. Alternatively, Swank (1993) assumed that vote intentions should shift depending upon which party's policy bias is best-suited for current economic conditions. Consequently, left-wing oriented parties should benefit from increases in unemployment and right-wing parties should gain support when inflation rises.

\subsection{Retrospective versus prospective voting}

Finally, we investigate whether vote intentions depend on retrospective or prospective evaluations of economic performance. On this matter, the results found in the literature are not conclusive. According to Nannestad and Paldam (1994: 228) "it appears that past events work almost the same as expected future ones in explaining vote decisions."

In this paper, data on the responses to seven questions of the Portuguese Consumer Survey are used to construct variables that reflect past and current economic conditions and expected future outcomes (see Appendix 1). The equation estimated is:

$$
\mathrm{VI}_{\mathrm{t}}=\alpha+\beta(\mathrm{L}) \mathrm{VI}_{\mathrm{t}-1}+\phi \mathrm{LEADER}_{\mathrm{t}}+\eta \mathrm{TIME}_{\mathrm{t}}+\theta \mathrm{CS}_{\mathrm{t}}+\mathrm{u}_{\mathrm{t}}
$$

Where CS is a vector of variables taken from INE's Consumer Survey.

\section{Results}

In this section we present OLS estimations of the models described above. We start by considering as dependent variable the vote intentions for the governing party. Then, we consider the government lead over the main opposition party, followed by the estimation of a SUR model of the vote intentions for the four main political parties. ${ }^{17}$ Finally, a discussion of the results obtained when using data from the Consumer Survey is presented.

\subsection{Vote intentions for the governing party, government lead, and main opposition party}

In our sample period, only two parties were in power (the PSD, until October 1995, and the PS afterwards), and all governments were single party. Results for our first set of estimations, using as dependent variable the percentage of vote intentions for the party in government, are shown in columns 1 and 2 of Table 3. 
Table 3. Vote intentions for the party in government and government lead over the major opposition party

\begin{tabular}{|c|c|c|c|c|}
\hline & \multicolumn{2}{|c|}{$\begin{array}{l}\text { Vote intentions for the } \\
\text { incumbent party }\end{array}$} & \multicolumn{2}{|c|}{$\begin{array}{l}\text { Incumbent's lead over } \\
\text { the major opposition } \\
\text { party }\end{array}$} \\
\hline & 1 & 2 & 3 & 4 \\
\hline Constant & $\begin{array}{l}32.28 \\
(5.18)^{* * *}\end{array}$ & $\begin{array}{l}36.50 \\
(4.82)^{* * *}\end{array}$ & $\begin{array}{l}26.24 \\
(3.93)^{* * *}\end{array}$ & $\begin{array}{l}33.70 \\
(3.44)^{* * *}\end{array}$ \\
\hline VI_Gov $(-1)$ & $\begin{array}{c}.56 \\
(8.95)^{* * *}\end{array}$ & $\begin{array}{c}.52 \\
(8.06)^{* * *}\end{array}$ & & \\
\hline Gov_Lead $(-1)$ & & & $\begin{array}{c}.60 \\
(11.12)^{* * *}\end{array}$ & $\begin{array}{c}.53 \\
(8.55)^{* * *}\end{array}$ \\
\hline Guterres / PS & $\begin{array}{l}-5.65 \\
(-2.93)^{* * *}\end{array}$ & $\begin{array}{l}-7.95 \\
(-2.09)^{* *}\end{array}$ & $\begin{array}{l}-7.91 \\
(-2.71)^{* * *}\end{array}$ & $\begin{array}{l}-9.69 \\
(-1.60)\end{array}$ \\
\hline H_Gov & $\begin{array}{c}.62 \\
(2.52)^{* *}\end{array}$ & $\begin{array}{c}.63 \\
(2.49)^{* *}\end{array}$ & $\begin{array}{c}.64 \\
(1.59)\end{array}$ & $\begin{array}{c}.70 \\
(1.66)^{*}\end{array}$ \\
\hline Time_Gov & $\begin{array}{l}-.08 \\
(-4.13)^{* * *}\end{array}$ & $\begin{array}{c}-.10 \\
(-3.89)^{* * *}\end{array}$ & $\begin{array}{l}-.12 \\
(-4.46)^{* * *}\end{array}$ & $\begin{array}{c}-.17 \\
(-4.19)^{* * *}\end{array}$ \\
\hline Inflation $(-1)$ & $\begin{array}{c}-.62 \\
(-3.21)^{* * *}\end{array}$ & & $\begin{array}{c}-.92 \\
(-3.13)^{* * *}\end{array}$ & \\
\hline (Inflation*PS) (-1) & & $\begin{array}{l}-.04 \\
(-.12)\end{array}$ & & $\begin{array}{l}.05 \\
(.10)\end{array}$ \\
\hline (Inflation*PSD) (-1) & & $\begin{array}{c}-.81 \\
(-3.13)^{* * *}\end{array}$ & & $\begin{array}{l}-1.29 \\
(-3.02)^{* * *}\end{array}$ \\
\hline Unemp_Rate (-1) & $\begin{array}{c}-.70 \\
(-2.89)^{* * *}\end{array}$ & & $\begin{array}{l}-1.29 \\
(-3.54)^{* * *}\end{array}$ & \\
\hline (Unemp_Rate*PS) (-1) & & $\begin{array}{l}-1.12 \\
(-2.55)^{* *}\end{array}$ & & $\begin{array}{l}-2.35 \\
(-3.53)^{* * *}\end{array}$ \\
\hline (Unemp_Rate*PSD) (-1) & & $\begin{array}{c}-.80 \\
(-2.51)^{* *}\end{array}$ & & $\begin{array}{l}-1.41 \\
(-2.58)^{* *}\end{array}$ \\
\hline Adjusted $\mathrm{R}^{2}$ & .75 & .77 & .79 & .79 \\
\hline \# Observations & 176 & 175 & 175 & 176 \\
\hline
\end{tabular}

Sources: OECD-MEI, Expresso, and National Elections Commission.

Notes. t-statistics are in parentheses;

Significance level at which the null hypothesis is rejected: ${ }^{* *}, 1 \%$; ${ }^{* *}, 5 \%$, and ${ }^{*}, 10 \%$; Newey-West heteroskedasticity and autocorrelation consistent standard errors and covariance;

Models estimated by OLS. 
In the estimation reported in column 1, we use as independent variables the first lag of the dependent variable (VI_GOV), ${ }^{18}$ a dummy (Guterres/PS) that takes the value of one when Guterres is Prime Minister and zero otherwise, a variable accounting for honeymoon effects (H_GOV), the number of months in office (Time_Gov), and one-month lagged values of the inflation rate (Inflation) $)^{19}$ and of the unemployment rate (Unemp_Rate). Results show that vote intentions for the party in office are positively affected by their value in the last month and by honeymoon effects. They also suggest that vote intentions are smaller when Guterres is Prime Minister (PS is in office), and that they tend to decrease with time in office ${ }^{20}$ and with increases in inflation or unemployment. ${ }^{21}$ Results regarding inflation and unemployment clearly support the responsibility hypothesis. Estimated coefficients associated with these two variables are negative and statistically significant at the $1 \%$ significance level.

Partisan effects are taken into account in the estimation of column 2 by multiplying the economic variables by dummy variables for the incumbent party. Results indicate that PSD governments are penalized for higher inflation, while PS governments are not. They also indicate that the latter tend to be more penalized for increases in the unemployment rate. These results are in sharp contrast with Swank's (1993) partisan hypothesis, according to which the right should gain more support when inflation rises and the left would be favored when unemployment increases. Our findings are consistent with the ideological responsibility hypothesis of Powell and Whitten (1993). They argue that a government should be held more responsible for the variables that it, or its constituency, care about the most.

The results of estimations that use the difference between the percentage of vote intentions for the party in office and that for the major party in the opposition as the dependent variable are shown in the last two columns of Table 3. Their similarity to those of the first two columns reinforces our conclusions. We have also analyzed vote intentions for the major opposition party, although these results are not reported in the paper. As expected, the significance of the variables was the same as for vote intentions for the governing party, and the signs of the estimated coefficients were symmetrically opposite.

\subsection{Vote intentions for the four main parties}

In this subsection, we performed estimations of vote functions for the four main political parties. Since vote intentions on one party may be correlated with those on other parties, the four equations were estimated as a system using the Seemingly Unrelated Regressions (SUR) technique. The explanatory variables are those of the previous regressions. Results are shown in Table 4. 
Table 4. Vote intentions on the four main political parties

\begin{tabular}{|c|c|c|c|c|}
\hline & PPD/PSD & PS & $\mathrm{CDS} / \mathrm{PP}$ & PCP \\
\hline Constant & $\begin{array}{l}15.84 \\
(2.49)^{* *}\end{array}$ & $\begin{array}{l}44.95 \\
(7.06)^{* * *}\end{array}$ & $\begin{array}{l}-2.83 \\
(-.92)\end{array}$ & $\begin{array}{c}2.75 \\
(1.03)\end{array}$ \\
\hline Vote Int. $(-1)$ & $\begin{array}{c}.48 \\
(10.27)^{* * *}\end{array}$ & $\begin{array}{c}.43 \\
(7.39)^{* * *}\end{array}$ & $\begin{array}{c}.62 \\
(11.53)^{* * *}\end{array}$ & $\begin{array}{c}.30 \\
(4.68)^{* * *}\end{array}$ \\
\hline Gov_PSD & $\begin{array}{l}19.57 \\
(2.58)^{* *}\end{array}$ & $\begin{array}{l}-41.65 \\
(-6.09)^{* * *}\end{array}$ & $\begin{array}{l}2.42 \\
(.67)\end{array}$ & $\begin{array}{l}-3.76 \\
(-1.20)\end{array}$ \\
\hline H_PSD & $\begin{array}{l}1.28 \\
(6.13)^{* * *}\end{array}$ & $\begin{array}{c}-.54 \\
(-3.40)^{* * *}\end{array}$ & $\begin{array}{c}-.10 \\
(-1.00)\end{array}$ & $\begin{array}{c}.26 \\
(3.00)^{* * *}\end{array}$ \\
\hline H-PS & $\begin{array}{c}-.37 \\
(-1.51)\end{array}$ & $\begin{array}{c}.48 \\
(2.45)^{* *}\end{array}$ & $\begin{array}{c}.08 \\
(.66)\end{array}$ & $\begin{array}{c}-.20 \\
(-1.86)^{*}\end{array}$ \\
\hline Time_Gov_PSD & $\begin{array}{c}-.09 \\
(-5.31)^{* * *}\end{array}$ & $\begin{array}{c}.09 \\
(6.39)^{* * *}\end{array}$ & $\begin{array}{c}.01 \\
(1.54)\end{array}$ & $\begin{array}{c}.003 \\
(.54)\end{array}$ \\
\hline Time_Gov_PS & $\begin{array}{r}.007 \\
(.13)\end{array}$ & $\begin{array}{c}-.24 \\
(-5.14)^{* * *}\end{array}$ & $\begin{array}{c}.05 \\
(1.83)^{*}\end{array}$ & $\begin{array}{c}.01 \\
(.63)\end{array}$ \\
\hline Inflation $(-1)^{*}$ Gov_PSD & $\begin{array}{c}-.71 \\
(-3.51)^{* * *}\end{array}$ & $\begin{array}{c}.57 \\
(3.81)^{* * *}\end{array}$ & $\begin{array}{l}-.005 \\
(-.06)\end{array}$ & $\begin{array}{c}.34 \\
(4.16)^{* * *}\end{array}$ \\
\hline Inflation $(-1)^{*}$ Gov_PS & $\begin{array}{l}-.32 \\
(-.80)\end{array}$ & $\begin{array}{c}.60 \\
(1.92)^{*}\end{array}$ & $\begin{array}{c}-.03 \\
(-.18)\end{array}$ & $\begin{array}{c}-.21 \\
(-1.22)\end{array}$ \\
\hline Unemp_Rate $(-1)^{*}$ Gov_PSD & $\begin{array}{c}-.61 \\
(-2.01)^{*}\end{array}$ & $\begin{array}{c}.71 \\
(3.00)^{* * *}\end{array}$ & $\begin{array}{c}.29 \\
(2.03)^{* *}\end{array}$ & $\begin{array}{c}.40 \\
(3.16)^{* * *}\end{array}$ \\
\hline Unemp_Rate $(-1)^{*}$ Gov_PS & $\begin{array}{l}-.03 \\
(-.04)\end{array}$ & $\begin{array}{l}-2.75 \\
(-4.14)^{* * *}\end{array}$ & $\begin{array}{c}.64 \\
(1.58)\end{array}$ & $\begin{array}{c}.17 \\
(.51)\end{array}$ \\
\hline Adjusted $\mathrm{R}^{2}$ & .84 & .88 & .67 & .59 \\
\hline \# Observations & 176 & 176 & 176 & 176 \\
\hline
\end{tabular}

Sources: OECD-MEI, Expresso, and National Elections Commission.

Notes. t-statistics are in parentheses;

significance level at which the null hypothesis is rejected: ${ }^{* *}, 1 \%$; ${ }^{* *}, 5 \%$, and ${ }^{*}, 10 \%$;

Models estimated by SUR.

The main conclusions suggested by the analysis of these estimations are the following. First, as expected, PSD and PS receive a greater percentage of vote intentions when in government, while vote intentions on the CDS/PP or PCP do not seem to depend on the governing party. Second, the PSD gains and the PS losses support during the honeymoon period of PSD governments (H_PSD = 1). The PS gains support during its honeymoon periods. Third, PSD governments lose support the longer they are in government 
(Time_Gov_PSD). PS governments also lose support the longer they hold office (Time_Gov_PS), and gain support the longer the PSD is in government. Fourth, higher inflation reduces favorable vote intentions for the PSD (when it is in government) and increases those for PS and PCP. Since our estimations show that only PSD governments were penalized for higher inflation, it is not surprising the parties of the opposition (or that stayed most of the time in the opposition) are benefited by inflation increases. Fifth, the PS and the PSD are penalized when unemployment increases during their governments, and the PSD gains support when unemployment rises when it is in the opposition. As in our tests for partisan effects reported in Table 3, PS governments are more penalized for unemployment increases than PSD governments. Finally, $\mathrm{CDS} / \mathrm{PP}$ and PCP, which were in the opposition during the entire sample period, gain support when unemployment rises during PSD governments (the estimation coefficient is also positive during PS governments, but it is not statistically significant). These results provide some additional evidence in favor of the responsibility hypothesis. Voters blame incumbent parties for bad economic results and, therefore, during economic hardships, opposition parties' receive more support.

\subsection{Vote intentions using INE's Consumer Survey}

Finally, we investigate whether voters are prospective or retrospective in their evaluations of incumbents' economic performance. As far as we know, this issue has never been investigated for the Portuguese case. We use for the purpose the National Institute of Statistics's (INE) monthly Consumer Survey, which consists of twelve questions. Data from seven of those questions are used in our estimations. They are related to the past and expected future economic situation of the household or country, inflation, and unemployment. A complete description of these variables is given in Appendix 1.

Since the economic situation of the households tends to be highly correlated with that of the country, and most people have rather static expectations, it is not surprising that there is high correlation between some of the variables resulting from the Consumer Survey (see the correlation matrix in Appendix 2). This makes it difficult to include more than one variable concerning the past or expected economic situation of the country/household in the same estimation, since it may lead to problems of multicollinearity.

The empirical results are presented in Table 5. The estimation of column 1 includes the evolution of the economic situation of the household in the last 12 months and the expectations for the next 12 months, together with the political explanatory variables used in the estimations of Table 3 . Vote intentions on the incumbent party increase when the situation of the household improved during the previous year, but do not seem to depend on the expecta- 
tions for the next year. Exactly the same happens in the estimation of column 2 , where the economic situation of the country is under consideration, instead of that of the household. Thus, it seems that Portuguese voters rely more on the recent evolution of the economic situation than on their expectations when evaluating the incumbent's performance. That is, they are retrospective.

Since the past and expected economic situations are highly correlated, the previous estimations may suffer from problems of multicollinearity. Thus, we decided to test for prospective or retrospective behavior using other combinations of variables. First, we used the perceived price increases in the last 12 months and the unemployment rate ${ }^{22}$ to represent recent economic conditions, and the expected price increases and evolution of unemployment for the next 12 months to represent future expected economic conditions (see column 3 ). As in the previous equations, only the variables representing the past are statistically significant. Second, in the estimation of column 4 , we used the evolution of the economic situation of the household in the last 12 months and the expectations for the evolution of prices and unemployment. Only the first variable was statistically significant. The same happens in column 5 , where we used the situation of the country instead of that of the household. Fourth, we used the expected economic situation of the household together with perceived past inflation and the unemployment rate (column 6). Again, only the variables representing the past and current economic situation are statistically significant. The same results were obtained in column 7 , where we used the expected situation of the country instead of that of the household.

In sum, there is clear evidence of retrospective voter behavior in all the estimation results shown in Table 5. Concerning the other variables, there is again evidence of personality, honeymoon and time effects on the vote intentions on the party in government.

\section{Conclusions}

The main objective of this paper was to investigate the determinants of vote intentions in Portugal. Do the Portuguese blame incumbents for the evolution of the economy? Does time in office influence vote intentions? Are parties held equally responsible for economic outcomes? Are voters retrospective or prospective? These are some of the questions that provided the starting point for the research. In order to answer them, we used two unexplored data sets consisting of vote intentions obtained from monthly polls performed since 1986 and of the results of the INE's monthly Consumer Survey.

Our paper provides additional light on the interactions between economics and politics in Portugal. In previous research, Veiga (1998) estimated popularity functions for the main political entities in Portugal. She found 


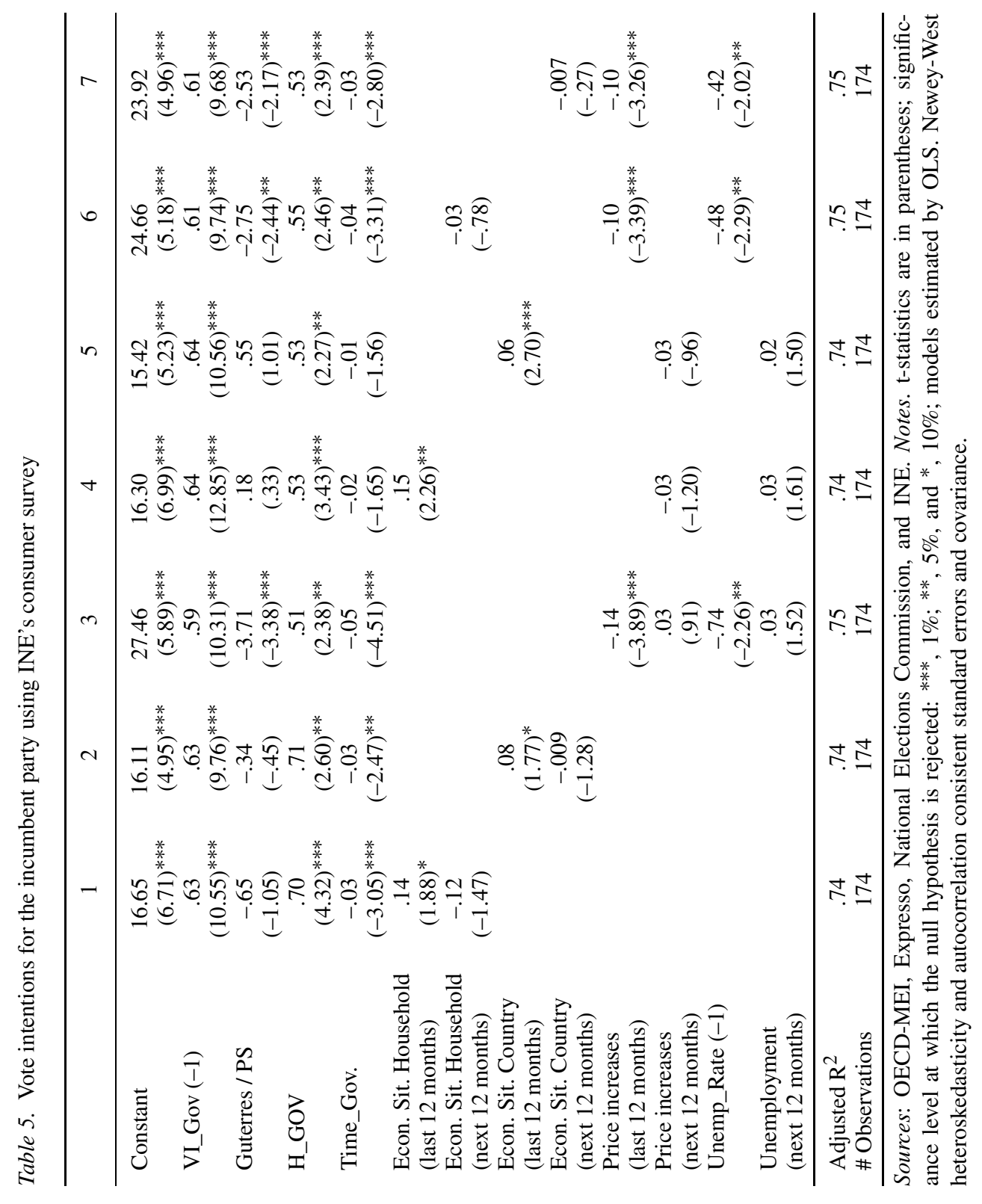


strong evidence in favor of the responsibility hypothesis, with unemployment, and to a lesser extent inflation, affecting popularity levels. Results found in this paper corroborate this conclusion: vote intentions in the incumbent party increase when the economy is performing well, while vote intentions in the opposition rise in the reverse case. Concerning partisan considerations, estimation results suggest that the Social Democrats are penalized for increases in inflation while the socialists are not, and that the latter are penalized more severely for increases in unemployment. These results clearly contradict Swank's (1993) partisan hypothesis but provide support for the ideological responsibility hypothesis of Powell and Whitten (1993).

According to the survey of Nannestad and Paldam (1994), there is no clear pattern on whether voters are prospective or retrospective. On the contrary, our results clearly reveal that Portuguese voters are retrospective.

Our analysis also shows that: (1) PS governments had less electoral support than PSD governments; (2) governments enjoyed a honeymoon period with the electorate during the first months of incumbency; (3) vote intentions for incumbent parties tend to decrease with time in office.

\section{Notes}

1. See Lewis-Beck (1988) and Nannestad and Paldam (1994) for surveys on vote-popularity functions, and Person and Tabellini (2000) for a recent survey on political economics. For a dissenting view that considered general economic conditions unimportant for election outcomes, see Stigler (1973).

2. Veiga (1998) estimated popularity functions for the Portuguese President of the Republic, Prime Minister, Government and Parliament.

3. For a more complete description of the evolution of the Portuguese political system, see Magone (1997), Colomer (1996), and several issues of Arthur Banks' Political Handbook of the World and of the World Europa Yearbook.

4. The Socialist Party was founded in 1875, declared illegal during the dictatorship (192674), re-emerging after the 1974 Revolution. The People's Democratic Party was founded in May 1974 and adopted its current designation of Social Democratic Party (PSD) in 1976.

5. Founded in 1974, the Democratic and Social Center added the designation of People's Party in 1993. It is a right-wing Christian democratic and conservative party. The Portuguese Communist Party was founded in 1921, banned in 1926, and legalized again in 1974. Since 1979, it formed several coalitions with small left-wing parties. The fact that it always fought for the establishment of a socialist regime in Portugal, in line with the revolutionist ideas of 1974, and rejected all revisions of the 1976 Constitution has prevented it from entering government coalitions. According to Magone (1997) the PCP has behaved as a "anti-system" party.

6. The PRD was a center-left party tacitly supported by the President Ramalho Eanes. In the 1987 election PRD's vote share decreased dramatically to 5\% and it almost disappeared in the 1991 elections. 
7. We used the measure of the effective number of parties suggested by Laakso and Taagepera (1979). This means that parties are weighted by their size (here, the percentage of votes cast). The effective number of parties is equal to $1 / \Sigma\left(\mathrm{p}_{\mathrm{i}}\right)^{2}$, where $\mathrm{p}_{\mathrm{i}}$ is the percentage of votes obtained by party $i$.

8. The Left Bloc managed to elect two deputies in 1999 and three in 2002.

9. In February 1986, Mário Soares won the second runoff of the most closely contested presidential election so far. He became the first civilian President of the Republic since 1974 and was re-elected in 1991.

10. Portugal joined the European Community on 1 January 1986.

11. In January 1996, Jorge Sampaio, also a former PS leader, succeeded Mário Soares in the Presidency. He was re-elected in January 2001.

12. This was the first time in the Portuguese Republic that a minority government completed a four-year term.

13. This electoral system benefited the two major parties, which are over-represented in terms of the number of seats in comparison with the proportion of votes cast. While the CDS and the PCP were generally not affected by the use of the Hondt method, the smaller parties have a hard time electing any deputies.

14. Fair (1978) created a vote model that combines these two views. His estimations of vote functions for the U.S. president indicated that current economic conditions affect votes for the President. Voters did not seem to look back very far and did not consider the past performance of a non-incumbent party. See Kirchgässner (1986) for an alternative theoretical model of the popularity function.

15. The confidence indicator is the average of consumer responses to a set of five questions regarding personal and national, present and future, economic conditions, extracted from the Portuguese Consumer Survey. These questions and the construction of the confidence indicator are described in Appendix 1.

16. See Lanoue and Headrick (1994) for a study focusing on Great Britain. Frey and Schneider (1978) used dummy variables to control for the popularity level of each U.S. president in their path-breaking study of popularity functions.

17. Unit-root tests performed for these series indicate that all of them are stationary. The t-statistics of Augmented Dickey-Fuller tests were: -4.53 for the vote intentions in the government party; -3.82 for the government lead; -3.34 for the main opposition party; -3.05 for PS; -3.34 for PSD; -3.80 for CDS/PP; and -3.49 for PCP. Since the critical values are -3.46 ( $1 \%$ level) and -2.87 (5\% level), the hypothesis of a unit root is clearly rejected for all the above-mentioned variables.

18. The number of lags of the dependent variable was chosen according to their statistical significance, in order to minimize the Schwarz Bayesian Information Criterion (SBIC), and to avoid problems of autocorrelation.

19. The inflation rate is defined as the percentage change in the Portuguese consumer price index since the same month of the previous year (homologous inflation rate).

20. Separating time in office for the PS and the PSD reveals that vote intentions for both governing parties declined with time in office in the same way (the hypothesis of equal coefficients cannot be rejected). When using dummy variables for terms in office, there is clear evidence that favorable vote intentions decrease over consecutive terms. If we include two variables accounting for honeymoon effects, one for PS and another for PSD governments, only the latter is statistically significant. All results, not reported here, are available from the authors upon request.

21. Other economic variables for which monthly data is available, such as the confidence index, the change in the industrial production index and in the real exchange rate, were 
added to the estimations. They are seldom statistically significant and results, not reported here, did not change significantly.

22. The INE's Consumer Survey does not include a question on perceived unemployment.

\section{References}

Alesina, A. and Cukierman, A. (1990). The politics of ambiguity. Quarterly Journal of Economics 105: 829-850.

Banks, A. (Ed.). Political handbook of the world. New York: McGraw-Hill. Several issues.

Colomer, J.M. (1996). Spain and Portugal: Rule by party leadership. In J.M. Colomer (Ed.), Political institutions in Europe, 170-210. London: Routledge.

Downs, A. (1957). An economic theory of democracy. New York: Harper and Row.

Fair, R.C. (1978). The effect of economic events on votes for President. The Review of Economics and Statistics 60: 159-173.

Frey, B.S. and Schneider, F. (1978). An empirical study of politico-economic interaction in the United States. Review of Economics and Statistics 60: 174-183.

Goodhart, C.A.E. and Bhansali, R.J. (1970). Political economy. Political Studies 18: 43-106.

Harrington, J. Jr. (1993). Economic policy, economic performance, and elections. American Economic Review 83: 27-42.

Hibbs, D.A. (1977). Political parties and macroeconomic policy. American Political Science Review 71: 1467-1487.

Kirchgässner, G. (1986). Economic conditions and the popularity of West German parties: A survey. European Journal of Political Research 14: 421-539.

Kramer, G.H. (1971). Short-term fluctuations in US voting behavior, 1896-1964. American Political Science Review 65: 131-143.

Laakso, M. and Taagepera, R. (1979). Effective number of parties: A measure with application to Western Europe. Comparative Political Studies 12: 3-21.

Lanoue, D.J. and Headrick, B. (1994). Prime Ministers, parties and the public: The dynamics of government popularity in Great Britain. Public Opinion Quarterly 58: 191-209.

Lewis-Beck, M.S. (1988). Economics and elections. Ann Arbor: The University of Michigan Press.

Magone, J.M. (1997), European Portugal: A difficult road to sustainable democracy. Riverside, NJ: Macmillan.

Mueller, J.E. (1970). Presidential popularity from Truman to Johnson. American Political Science Review 64: 18-23.

Nannestad, P. and Paldam, M. (1994). The VP-function: A survey of the literature on vote and popularity functions after 25 years. Public Choice 79: 213-245.

Person, T. and Tabbellini, G. (2000). Political economics - explaining economic policy. Cambridge, MA and London, U.K.: The MIT Press.

Powell, G.B. Jr. and Whitten, G.D. (1993). A cross-national analysis of economic voting: Taking account of the political context. American Journal of Political Science 37: 391414.

Rogoff, K. and Sibert, A. (1988). Elections and macroeconomic cycles. Review of Economic Studies 55: 1-16.

Smyth, D.J., Washburn, S.K. and Dua, P. (1989). Social preferences, inflation, unemployment, and political business cycles: Econometric evidence for the Reagan Presidency. Southern Economic Journal 56: 336-348. 
Stigler, G. (1973). General economic conditions and national elections. American Economic Review, Papers and Proceedings 63: 308-315.

Swank, O.H. (1993). Popularity functions based on partisan theory. Public Choice 75: 339 356.

Veiga, L.G. (1998). Popularity functions for the Portuguese Prime Minister, Government, Parliament and President. European Journal of Political Research 33: 347-361.

World Europa Yearbook. London: Europa Publications. Several issues. 


\section{Appendix 1}

The seven questions from the National Institute of Statistics's (INE) monthly Consumer Survey that we use in this paper are the following:

1. In your opinion, during the last 12 months, your household's (family) economic situation...
a improved a lot
b improved a little
c did not change
d worsened a little
e worsened a lot
f does not know

2. In your opinion, during the next 12 months, your household's (family) economic situation ...
a. will improve a lot
b. will improve a little
c. will not change
d. will worsen a little
e. will worsen a lot
f. does not know

3. In your opinion, during the last 12 months, the general economic situation of the country
a. improved a lot
b. improved a little
c. did not change
d. worsened a little
e. worsened a lot
f. does not know

4. In your opinion, during the next 12 months, the general economic situation of the country ...
a. will improve a lot
b. will improve a little
c. will not change
d. will worsen a little
e. will worsen a lot
f. does not know 
5. In your opinion, during the last 12 months, prices ...
a. increased a lot
b. increased
c. increased a little
d. did not change
e. decreased a little
f. does not know

6. In your opinion, having the current situation in mind, do you think prices, during the next 12 months ...
a. will increase more rapidly
b. will increase as much as now
c. will increase less rapidly
d. will stay the same
e. will decrease slightly
f. does not know

7. In your opinion, during the next 12 months, national unemployment ...
a. will increase a lot
b. will increase a little
c. will not change
d. will decrease a little
e. will decrease a lot
f. does not know

For each question, the result is the weighted difference of the percentages of positive and negative answers, using the following equation:

$$
Q_{i}=(a+0.5 b)-(0.5 d+e)
$$

where a,b,d and e are the percentages of respondents choosing the respective options.

\section{Confidence indicator}

The Confidence Indicator corresponds to the simple arithmetic average of the results obtained for five questions of the Consumer Survey: questions 1 to 4 , shown in the previous page, and the following question: 
8. Do you think that, for people in general, this is a good time to buy important durable goods, such as furniture, washing machines, TV sets, VCRs, computers, etc.?
a. Yes, it is a good time
b. It is neither a good nor a bad time
c. No, it is not a good time. Those acquisitions should be postponed
d. does not know

The result for this question is the difference between the percentage of respondents choosing option a and option c. That is:

$$
\mathrm{Q}_{8}=\mathrm{a}-\mathrm{c}
$$

Then, the Confidence Indicator is obtained using the following equation:

$$
\mathrm{CI}=\left(\mathrm{Q}_{1}+\mathrm{Q}_{2}+\mathrm{Q}_{3}+\mathrm{Q}_{4}+\mathrm{Q}_{8}\right) / 5
$$

\section{Appendix 2}

Correlation matrix: Data on the first seven questions of the Consumer Survey

$\begin{array}{llllllll} & \text { Q 1 } & \text { Q 2 } & \text { Q 3 } & \text { Q 4 } & \text { Q 5 } & \text { Q 6 } & \text { Q 7 } \\ \text { Q1 } & 1.00000 & & & & & & \\ \text { Q2 } & 0.85369 & 1.00000 & & & & & \\ \text { Q3 } & 0.93390 & 0.89532 & 1.00000 & & & & \\ \text { Q4 } & 0.80934 & 0.95718 & 0.91517 & 1.00000 & & & \\ \text { Q5 } & 0.02153 & 0.10747 & 0.04071 & 0.02650 & 1.00000 & & \\ \text { Q6 } & -0.04375 & -0.28544 & -0.17452 & -0.40850 & 0.51535 & 1.00000 & \\ \text { Q7 } & -0.83320 & -0.66293 & -0.72650 & -0.62785 & -0.08003 & -0.04018 & 1.0000\end{array}$

